\title{
Transplants and Indigenous Peoples: An Initial Approach
}

\author{
Estevão Rafael Fernandes ${ }^{1}$ (D), Ana Karoline Nóbrega Cavalcanti ${ }^{2}$
}

1. Universidade Federal de Rondônia RóR Porto Velho (RO), Brazil.

2. Secretaria de Estado de Saúde - Porto Velho (RO), Brazil.

\section{doi) https://doi.org/10.53855/bjt.v25i1.439_in}

Correspondence author:

estevaofernandes@gmail.com

Section Editor

Ilka Boin

Received

Jan. 12, 2022

Approved

Jan. 13, 2022

Conflict of interest

Nothing to declare

How to Cite

Fernandes ER, Cavalcanti AKN. Transplants and Indigenous Peoples: An Initial Approach. BJT. 2022; 25(01): e0122. https://doi.org/10. 53855/bjt.v25i1.439_in

eISSN

2764-1589

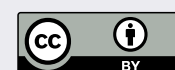

\begin{abstract}
This article indicates a set of issues related to transplants involving indigenous people. This is a topic not addressed in the literature of the country and for which it is relevant to take a closer look, given not only medical aspects, but also bioethical, socio cosmological, religious, social and cultural aspects. From an interdisciplinary perspective, we sought to draw attention to the importance of taking into account aspects related to the constitution of the indigenous person; implications regarding informed consent; and the need for a sensitive look at the intercultural differences involved. The conclusion was that it is necessary to form a protocol together with indigenous organizations and official bodies that consider cultural specificities. In addition, a survey of both institutional initiatives in other countries and the literature on the subject is still a task to be carried out in Brazil.
\end{abstract}

Descriptors: Indigenous people; Health of Indigenous Peoples; Obtaining Tissues and Organs.

\section{INTRODUCTION}

Brazil is an ethnically diverse country. In its territory, there are more than 300 ethnic groups, speaking about 280 different languages. Although these indigenous people populate the imagination as untouched, in the middle of the Amazon, approximately $40 \%$ of the Brazilian indigenous population lives in urban environments, according to estimates by the Instituto Brasileiro de Geografia e Estatística $^{1}$ (Brazilian Institute of Geography and Statistics)

From a health point of view, several of these peoples are already facing the so-called "epidemiological transition", with an increasing number of deaths caused by chronic diseases - such as obesity, diabetes, kidney problems, heart problems, for example -, a direct or indirect consequence of contact with the surrounding society. Likewise, problems such as lack of basic sanitation, pollution from mining or direct contact with pesticides ${ }^{3}$ daily and systematically affect indigenous communities, including isolated peoples. In this context, it can be said that it is only a matter of time before there is a growing demand for transplants by this population, something that has so far been little faced both by the country's literature and by managers and legislators.

It is no longer a matter of considering indigenous peoples in the national territory as alien to the more general demands and problems of the population as a whole, but, on the contrary, to seek to extend to them all the assistance to which they are entitled, provided that specific aspects of their cultures are respected. 


\section{DISCUSSION}

These initial considerations lead to a question: what issues should be taken into account in transplants involving indigenous peoples?

Given the limits of this text, we think it is important to emphasize three aspects above all, given this problem. First, there are the specifics of working from another person's perspective. Having said that briefly - this point will be developed further - in the West the notion of a person is confused with that of Homo sapiens. In indigenous peoples, on the other hand, as the ways of classifying the world are diverse and not based on our biological assumptions, a subject becomes a person through a series of complex social and ritual relationships. The body is not, in these societies, a mere physical artifact, but the sum of social and cosmological relationships understood solely on the basis of their cultures.

Second, it is necessary to indicate practical implications regarding informed consent: how to obtain it in the best possible way, in an intercultural context?

Finally, we sought to draw attention to the importance of a sensitive look at these cultural differences and to a significant assumption when dealing with this type of problem: the intervention in an indigenous body has repercussions throughout its community in several different ways, and, with regard to transplants, this intervention becomes considerably more complex. It was concluded here that the constitution, together with indigenous organizations and indigenist bodies, of a protocol that regulates transplants in intercultural contexts is relevant, as a way of protecting both indigenous communities and medical teams across the country.

Having made these considerations, it is interesting to point out how the issue of transplants involving indigenous people does not cause alarm among researchers in Brazil. Searching in the main databases in the health area (PubMed, Latin American and Caribbean Literature on Health Sciences - Lilacs, Online Scientific Electronic Library - SciELO, among others), through descriptors such as indígenas ou povos indígenas and transplante, what was seen was the complete lack of texts produced on the subject - even in important references about indigenous health in the country. Furthermore, even though we have a relatively advanced policy targeting the Indigenous Health Care Subsystem, it is important to point out that the Política Nacional de Atenção à Saúde dos Povos Indígenas (National Health Care Policy for Indigenous Peoples), approved in 2002, it makes no mention of the word transplant even once in its entire text.

This void on the subject in the Brazilian context calls attention to what is produced outside the country, in the academy or beyond. A quick search using the same descriptors leads to several texts on the topic in different national and cultural contexts - some examples make this diversity clear. ${ }^{5-11}$

Institutionally, there are several successful official initiatives being developed or underway in other countries in order to think about transplants in indigenous people. Suffice it to say that the U.S. Department of Health and Human Services' Office of Minority Health - the equivalent of our Ministério da Saúde - has a specific website on organ donation for Native Americans from the continental United States and Alaska. ${ }^{12}$ In that country, according to information available on the website, 280 transplants were performed involving indigenous people in 2020, when there were more than 900 Native Americans awaiting kidney, liver, lung and heart transplants.

In Canada, in turn, there are cell phone applications aimed at people belonging to first nations, such as the Kidney Check Program, or initiatives to discuss how the health system can accommodate indigenous patients and their families in actions related to organ transplants - as in the virtual meeting held in December 2021, promoted in collaboration with the Network Environments for Indigenous Health Research National Coordinating Centre, the First Nations and Métis Organ Donation and Transplantation Network and the Can-SOLVE CKD Network (Fig. 1)

There is no space here to analyze, in a detailed and deserved way, the differences between indigenous policies in these national contexts - it is hoped to do so in the future, as well as an exercise in reviewing this literature. It is enough, here, to point out in a preliminary way that such sensitivity is the result not only of a long journey of demands from the indigenous movements organized in these countries, but also of a different relationship in institutional terms with such peoples on the part of these States and built historically. ${ }^{14}$

However, there is a specific point that directly interests those who seek to think about transplants and indigenous peoples from a legal perspective. In Brazil, we have an indigenist legislation born during the military regime - the Estatuto do Indio (Indigenous Statute)is from 1973 - based on the idea of guardianship. The objective was to "integrate the Indigenous peoples peacefully into the National Union", exercising all possible control over these communities, especially in light of the Doutrina de Segurança Nacional. ${ }^{15}$ (National Security Doctrine). The concept of cultural autonomy only came to be respected with the Federal Constitution of 1988, but even so, respect for indigenous cultures, provided for in Article 231 of the Constitutional Charter, remains, until today, under the scrutiny of the tutor - that is, the Fundação Nacional do Índio-FUNAI (National Indigenous Foundation). In short, this means that any intervention, such as a transplant, for example, given the lack of a specific legal provision or clearly and collaboratively constituted protocols, can easily turn into a bureaucratic and legal battleground involving FUNAI, Attorney General's Office (AGU), 


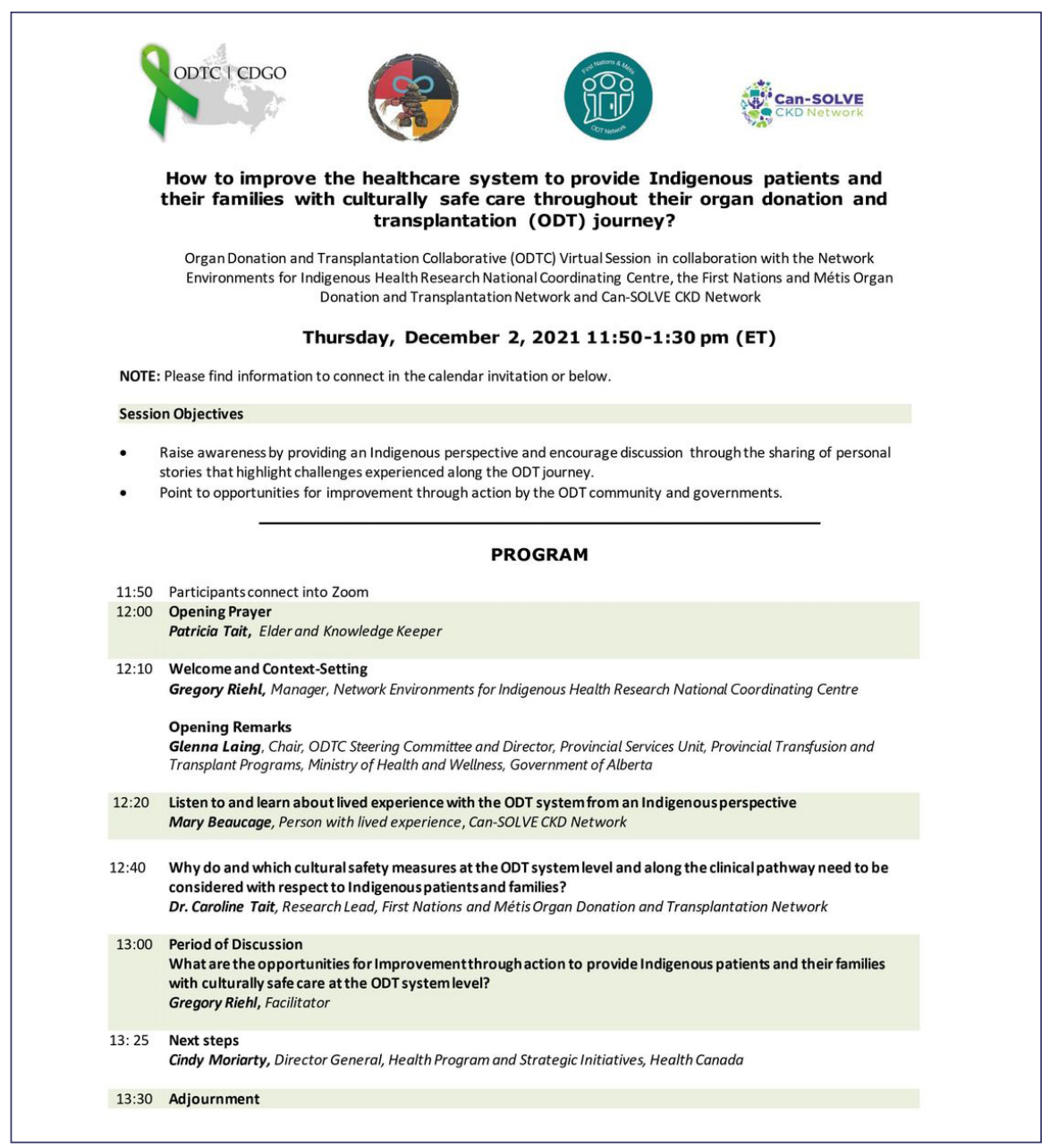

Source: First Nations and Métis Organ Donation and Transplantation Network.13

Figure 1. Organ donation and transplantation collaborative, Canada.

the Ministries of Health, Human Rights, Justice, Public, indigenous organizations, among others. The idea of a protocol would not only support the health teams, but also protect the culture of these peoples and their own notions of health, illness and the person.

It is important to point out that this is not just about respecting indigenous cultures - that is, a moral presupposition, but also a norm established since the signing of Convention 169 of the International Labor Organization (ILO), which became law in Brazil. in 2004, establishing the obligation of prior and informed consultation to indigenous peoples about decisions that directly impact their lives.

The point here is: how would a transplant, for example, impact these societies from the perspective of their cultures and how to mitigate these impacts?

As mentioned earlier, the notion of person among indigenous peoples is a good starting point for understanding this type of problem. The issue has been investigated within the scope of Brazilian anthropology for over 40 years $^{16}$ and can be summarized as follows: the Amerindigenous body is constructed from a set of symbolic, ritual, kinship and naming relationships. In other words, the subject becomes a meeting place for various social relationships, being constructed and understood by native categories of thought. What Westerners understand as individuals in indigenous peoples gives way to a social unit that operates in relation to kinship networks, mythologies, cosmologies and native perspectives on nature, for example. Since the subject is this crossing of symbolic chains, he must be understood based on them, in such a way that an action on the native body is, as a rule, something that affects the entire corpus of that society.

How does this work in practice? One of the authors of this text had the opportunity to analyze, some years ago ${ }^{17}$ ideologies around the concept of person among the indigenous Jê natives of Central Brazil, allowing us to give an example of how these concepts operate in these peoples. In summary, in some societies, the fetus is seen as a substance directly linked to the father and his consanguineous relatives, in such a way that any food ingested by his father, uncles, paternal grandfather and parallel cousins affects the child's body for several years afterward. the birth. This leads to a series of restrictions and dietary taboos on the part of 
these people, in order to protect their health: if an uncle eats armadillo meat, the child will eat dirt; if their father eats beans, their skin will turn black, etc. It is common, for example, to look for someone to blame for breaking these taboos in case of more serious illnesses, in order to restore their health. Children in these societies spend years without a proper name, as they have to wait for their bodies to be strong enough to bear a name - that is, to have relative autonomy as subjects - and yet there are several name changes throughout life, marking important changes in the status of these people: new landmarks in their bodies, in the rituals in which they participate, in the roles they occupy in their communities, among others. Another well-known and well-documented example concerns the blood samples of the native Yanomami (Roraima/Amazonas) taken by researchers from the United States in the 1960s and 70s. For more than four decades, Yanomami leaders sought to recover these samples in order to appease the spirits of those deceased people whose blood had been taken. In that culture, the dead must be cremated in a series of complex rituals, and the frozen blood in some university prevented such a ceremony, since some of those people had not gone through these rites.

Examples in this sense are legion and indicate what has been tried to point out here: processes of health, illness, corporeality, healing and care among indigenous peoples, in general, are a relevant part of the collective life of these societies and can only be understood in the light of their cultures. As the indigenous person is a social constitution, these interventions also have social repercussions.

This leads to another point: the bioethical repercussions of these issues in practice. Much is known about the Resolution of the Conselho Nacional de Saúde (CNS) no 466/2012, which establishes the guidelines for research on human beings, but attention is drawn here to two other relatively little known standards. The first, $\mathrm{n}^{\circ} 304 / 2000$, still in force (even though it was made under Resolution $n^{\circ}$ 196/1996), concerns ethics in research specifically with indigenous peoples. The second standard is CNS Resolution No. 510/2016, which regulates the human sciences in research that may pose risks to everyday life.

These two norms are brought here because they provide some important guidelines regarding possible approaches in the search for consent, in case of transplantation involving indigenous people. Such guidelines are suggestions and can be readjusted, and the ideal - it is repeated - would be the creation of a specific protocol aimed at these populations. Important issues such as respect for cultural particularities and native decision-making spheres are well established, but lack, for example, the provision for the use of interpreters or translators to assist in those procedures in which those involved do not have full knowledge of the Portuguese language. As precious as it may seem, by way of comparison, some women's service stations in the country have women interpreters in order to assist in the reception of indigenous victims of violence. After all, even those who live close to urban centers are not necessarily able to fully communicate in Portuguese.

\section{CONCLUSION}

It was seen that transplantation involving indigenous peoples in Brazil is still something to be faced by both legislators and managers and researchers. Although there is an accumulation of literature and some initiatives in other countries in this sense, the topic has not raised further reflections in Brazilian lands. This article is a first step in that direction. One of our hypotheses is that the epidemiological transition registered in several of these communities and various social and environmental problems will soon give rise to a demand for transplants by these peoples, as is the case in other countries.

Throughout this text, we sought to show, albeit briefly, how cultural issues have direct implications when thinking about transplantation in an intercultural perspective: Amerindigenous corporeality and person are part of a complex set of social and cultural relations which must be respected and considered in this type of intervention. However, given this complexity, the construction, in partnership with indigenous organizations and state agencies, of a transplant protocol that takes these specificities into account is suggested.

In addition, the task of carrying out a detailed survey of the literature on transplants in indigenous peoples in other national contexts, as well as initiatives carried out in other countries, in order to learn from these experiences, seems urgent.

\section{AUTHORS' CONTRIBUTION}

Substantive scientific and intellectual contributions to the study: Fernandes ER and Cavalcanti AKN; Conception and design: Fernandes ER and Cavalcanti AKN.

\section{DATA STATEMENT AVAILABILITY}

All data were generated or analyzed in the present study. 


\section{FUNDING}

Not applicable.

\section{ACKNOWLEDGEMENTS}

Not applicable.

\section{REFERENCES}

1. Instituto Brasileiro de Geografia e Estatística (IBGE). Indígenas. Gráficos e tabelas [Internet]. Brasil: IBGE [accessed on 17 jan. 2022]. Available at: https://indigenas.ibge.gov.br/graficos-e-tabelas-2.html

2. Coimbra Jr. CE, Flowers NM, Salzano F, Santos RV. Xavante in transition: health, ecology and bioanthropology in Central Brazil. Ann Arbor: University of Michigan Press; 2002.

3. Gonçalves GMS, Gurgel IGD, Costa AM, Almeida LR, Lima TFP, Silva E. Uso de agrotóxicos e a relação com a saúde na etnia Xukuru do Ororubá, Pernambuco, Brasil. Saúde Soc. 2012;21(4):1001-12. https://doi.org/10.1590/S0104-12902012000400017

4. Buchillet D. Bibliografia crítica da saúde indígena no Brasil (1844-2006). Quito: Abya-Yala; 2007.

5. Howson P, Irish AB, D’orsogna L, Chakera A, Swaminathan R, Perry G, et al. Allograft and Patient Outcomes Between Indigenous and Nonindigenous Kidney Transplant Recipients. Transplantation. 2020;104(4):847-55. https://doi.org/10.1097/ TP.0000000000002891

6. Barraclough KA, Grace BS, Lawton PMSP, McDonald SP. Residential location and kidney transplant outcomes in indigenous compared with nonindigenous Australians. Transplantation. 2016;100(10):2168-76. https://doi.org/10.1097/ TP.0000000000001007

7. Keddis MT, Sharma A, Ilyas M, Zhang N, Khamash H, Leischow SJ, et al. Transplant center assessment of the inequity in the kidney transplant process and outcomes for the Indigenous American patients. PLoS One. 2018;13(11):e0207819. https://doi. org/10.1371/journal.pone.0207819

8. Khanal N, Lawton PD, Cass A, McDonald SP. Disparity of access to kidney transplantation by Indigenous and non-Indigenous Australians. Med J Aust. 2018;209(6):261-6. https://doi.org/10.5694/mja18.00304

9. Walker RC, Abel S, Reynolds A, Palmer SC, Walker C, Tipene-Leach DC. Experiences, perspectives and values of Indigenous peoples regarding kidney transplantation: systematic review and thematic synthesis of qualitative studies. Int J Equity Health. 2019;18:204. https://doi.org/10.1186/s12939-019-1115-y

10. Majoni SW, Ullah S, Collett J, Hughes JT, McDonald S. Weight change trajectories in Aboriginal and Torres Strait islander Australians after kidney transplantation: a cohort analysis using the Australia and New Zealand Dialysis and Transplant registry (ANZDATA). BMC Nephrol. 2019;20:232. https://doi.org/10.1186/s12882-019-1411-1

11. Boan P, Swaminathan R, Irish A. Infectious complications in indigenous renal transplant recipients in Western Australia. Intern Med J. 2017;47(6):648-55. https://doi.org/10.1111/imj.13450

12. U.S. Departament of Health and Human Services. Organ Donation and American Indians/Alaska Natives. Estados Unidos: U.S. Departament of Health and Human Services, Office of Minority Health; 2021.

13. First Nations and Métis Organ Donation and Transplantation Network. Facebook [Internet]. [accessed on jan. 2022]. Available at: https://www.facebook.com/pg/FirstNationsMetisODT

14. Fernandes ER. Descolonizando sexualidades: enquadramentos coloniais e homossexualidade indígena no Brasil e nos Estados Unidos. Brasília: Editora Universidade de Brasília; 2020. https://doi.org/10.26512/9786558460442

15. Lima ACS. Um grande cerco de paz: poder tutelar, indianidade e formação do Estado no Brasil. Petrópolis: Vozes; 1995.

16. Seeger A, Matta R, Viveiros de Castro E. A construção da pessoa nas sociedades indígenas brasileiras. Boletim do Museu Nacional. 1979:2-19. Série Antropologia.

17. Fernandes ER. Do Tsihuri ao Waradzu: o que as ideologias xavante de concepção, substância e formação da pessoa nos dizem sobre o estatuto ontológico do outro? Horiz Antropol. 2010;16(34):453-77. https://doi.org/10.1590/S0104-71832010000200019 